\title{
OUDHEIDKUNDIGE AANTEEKENINGEN
}

DOOR

Dr. W. F. STUTTERHEIM.

\section{XLVI. $\left.{ }^{*}\right)$ \\ De oudste inscriptie van Oost-Java?}

Tijdens mijn bezoek aan enkele oudheden in Java's Oosthoek in de maand December 1933 bracht de heer H. R. van Heekeren mij bij den onder den naam Batoe gong of Batoe taboehan bekend staanden steen dichtbij den driesprong te Rambi poedji, waar zich van den weg Loemadjang-Djěmběr die naar Poegěr afbuigt ${ }^{1}$ ). De steen, een blok andesiet van natuurlijke vormen, is van den weg af duidelijk zichtbaar en heeft, ten ruwste gemeten, bij een hoogte van \pm 120 $\mathrm{cm}$. een lengte van $\pm 170 \mathrm{~cm}$. Hij zou eenmaal boven op den heuvel gelegen hebben, welke zich in den djati-aanplant aan genoemden driesprong bevindt, en is kahoelan. De het eerst in het oog vallende merkwaardigheid, welke hij vertoont, is, dat zich op een der vele vlakken, welke hij bezit, en hetwelk blijkbaar opzettelijk effen gemaakt is, een sterk afgeknot-kegelvormige verhevenheid bevindt, welke ongeveer $20 \mathrm{~cm}$. buiten dat vlak uitsteekt en aan het grondvlak een diameter heeft van $60-65 \mathrm{~cm}$. (de kegel is namelijk niet cirkelrond). Deze verhevenheid maakt den indruk van een speling der natuur te zijn, dan wel tot een dier nog onverklaarde versieringen te behooren, waaraan verschillende megalieten rijk zijn. De meening, dat wij een megaliet voor ons hebben! zou dan ook voor deze aan megalieten zoo rijke streek niets bevreemdends bevatten, ware het niet, dat zich op een der aan het genoemde grenzende vlakken (aan den onderkant van den steen), dat echter niet zoo glad is behakt, een korte inscriptie bevond in een kennelijk oud schrift ${ }^{2}$ ). Het is

*) Zie deze Bijdragen, dl. 85 , 1929, bl. 479 ; dl. 86,1930 , bl. 302 en 557 ; dl. 89,1932 , bl. 97 en 261 ; dl. 90,1933 , bl. 267 ; dl. 92 , 1934, bl. 181.

1) De steen komt niet in den Inventaris van 1923 voor.

2) Overigens behoeft de aanwezigheid der inscriptie natuurlijk de mogelijkD1. 95 . 
deze inscriptie, welke ik, hoewel de inhoud niet veel te beteekenen heeft, toch om haar letterschrift in het ondervolgende wil bespreken.

Omtrent den inhoud van de inscriptie valt weinig te zeggen. Er staat zeer duidelijk parzerwateçwara, „Bergheer”, hetgeen op niemand anders dan Çiwa kan slaan. In verband met deze beteekenis vraag ik mij dan ook af, of de afgeknotte kegel niet het restant is van een eenmaal hoogeren kegel of cylinder, met andere woorden: van een lingga. Een aannemelijker verklaring van bedoeld voorwerp weet ik in verband met de inscriptie niet aan de hand te doen ${ }^{1}$ ).

Meer valt te zeggen omtrent de gebezigde schriftsoort. Onmiddellijk valt het op, dat wij hier, in een streek, welke wij gewoonlijk beschouwen als van geen of weinig cultureele beteekenis in de oudjavaansche geschiedenis en die wij hoogstens met de periode van Majapahit in verband zouden willen brengen, een schriftsoort gebruikt zien, die ouder is dan die van Majapahit, ja, ouder dan die der onmiddellijk voorafgaande dynastieën.

Het is voornamelijk de combinatie revera, welke in de bovengeschreven $r a$ dien hoekigen en van een ,kop” voorzienen vorm vertoont, welken wij te vergeefs zoeken in alle oostjavaansche inscripties, met uitzondering van die van Dinaja ${ }^{2}$ ). Daar komt deze vorm een enkele maal voor, zoodat wij reeds op grond van dit verschijnsel geneigd zouden zijn onze inscriptie aan de eeuw van Dinaja, de 8e A.D., toe te schrijven, ware het niet, dat er zich bij enkele andere letterteekens kenmerken voordoen, welke op een hoogeren ouderdom kunnen wijzen.

In de eerste plaats geldt dit voor de $t a$.

Zooals men weet, heeft de oorspronkelijke Pallawa-ta zijn langen hals slechts behouden tot en met de inscriptie van Sañjaya uit 732 . Reeds in de inscriptie van Dinaja echter treffen wij de latere

heid niet uit te sluiten, dat wij een megaliet voor ons hebben. De inscriptie kan een poging geweest zijn om een vanouds vereerd voorwerp op te nemen in een nieuwen cultus, iets, waarvan talrijke vcorbeelden elders zijn aan te voeren.

1) Tenzij dan de steen inderdaad een megaliet was (zie vorige noot).

2) Zie T.B.G. 1916 tegenover pag. 411, regel 4 swargga, r. 11 darç̧i. Elders in deze inscriptie is deze $r a$ echter meer recht of gebogen, niet hoekig. Het is te betreuren, dat in T.B.G. 1924 tegenover pag. 228 een zeer slechte reproductie der inscriptie is afgedrukt, welke van verschillende letterteekens slechts gedeelten te zien geeft en daardoor verwarrend werkt. Voor het middenstuk is dat natuurlijk geen bezwaar, aangezien wij daarvoor over een betere reproductie beschikken. 
middenjavaansche $t a$ aan, welke hoogstens van een kort streepje aan den bovenkant is voorzien, als rudimentair overblijfsel van den oorspronkelijken hals ${ }^{1}$ ). Hier vinden wij nu de $t a$ in haren oorspronkelijken vorm terug. Niettemin kan het feit, dat het teeken voorzien is van een ,nail-head", en niet van de in de oudste inscripties van den Archipel voorkomende ,box-head”, ons er voor behoeden den ouderdom te hoog op te voeren ${ }^{2}$ ).

Een ander teeken, dat een hoogen ouderdom verraadt, is dat der $r a$. Het is namelijk bijna identiek aan dat, hetwelk wij aantreffen in de inscripties van Moeara Kaman (Borneo), en bestaat uit een van een ,nail-head" voorziene verticale streep, waarvan de onderste punt naar links ombuigt. Het verschil tusschen beide teekens is dus weer gelegen in het gebruik van een ,nail-head" in de plaats van een „box-head" ${ }^{3}$ ).

Men vergisse zich voorts met dit teeken niet; wel is waar lijkt een bepaalde vorm der later voorkomende $r a$ 's er eenigszins op, doch daar vinden wij steeds de eigenaardigheid, dat de ,nail-head" los is geraakt van de verticale streep en daarenboven het karakter van een streepje heeft aangenomen (zooals dus bij de $t a$ van Dinaja het geval was), welk streepje dan naar rechts afhellend is aangebracht. Meestal vindt men daarenboven dan een lichten of sterkeren knik in het verticale been ${ }^{4}$ ).

Het teeken voor $\varsigma^{a}$ kan ons weinig leeren, daar het vrijwel uniek is. De horizontale streep is hier namelijk aan beide einden aan den boog aangesloten, terwijl het rechterbeen door de aanhechting van de wa zoozeer in de verdrukking is gekomen, dat niet meer kan worden nagegaan, of het gewoonlijk wel werd gevonden. Niettemin wijst de sterk ontwikkelde krul aan het vooreinde naar de westjavaansche inscripties, met name die van Djamboe en $\mathrm{Tji}$

1) Waar deze streepjes ook nog op een hals staan, wijken zij toch af van het "nail-head"-type en bestaan zij uit een slechts aan den rechterkant uitstekend streepje (vlaggetje).

2) Zie Vogel in Bijdragen 74: 222 en P.O.D. deel I: 34. Hoewel de term „nail-head" slechts voor het nāgari-schrift wordt gebezigd, neem ik hem hier over om de gelijksoortige koppen der Kawi-karakters te typeeren.

3) Zie Bijdragen 74: 232 plaat A regel 9, B regel 2, 4, 8, C regel 1, 4. Zie VogeL's opmerkingen daarbij op pag. 223 vlg., waarbij deze geleerde dit haakje dateert tusschen de Bhadrawarman-inscripties van Campā en die van Singhawarman Pallawa.

4) Zie de tabellen van HoLLE. 
Aroeteun, hoewel in de Tjanggal-inscriptie ook een enkel geval kan worden gevonden ${ }^{1}$ ).

De vorm van de $w a$ en die van de $p a$ wijken echter tamelijk sterk af van die der oudste inscripties; daar toch vinden wij doorgaans een knik in het voorste been van de $p a$ en een inbuiging in de basis van de $w a$. Niettemin vindt men ook daar in enkele gevallen dezelfde vormen als te Rambi poedji ${ }^{2}$ ).

Het teeken voor de $e$ ten slotte kan ons niet veel zeggen, daar het in dezen vorm zoowel bij de oudste als bij latere inscripties voorkomt.

Onze opmerkingen overziende, kunnen wij dus voorloopig constateeren, dat met name de teekens voor $t a$ en $r a$ het vermoeden wettigen, dat onze inscriptie ouder moet zijn dan die van Dinaja uit 760 en dus als de oudste inscriptie van Oost-Java te boek zou moeten worden gesteld.

Een andere vraag is het echter, hoe oud zij dan wel kan zijn.

Zooals wij zagen, wijzen enkele teekens naar de inscripties uit de $4 \mathrm{e}$ en $5 \mathrm{e}$ eeuw, terwijl dit weer te niet gedaan wordt door het feit, dat de voor die inscripties zoo typeerende ,,box-heads" ontbreken en vervangen zijn door ",nail-heads”, welke weer met de inscripties van Toek Mas uit \pm 650 en Tjanggal uit 732 overeenkomen. Afwijkend van de laatste is echter in sterke mate de $r a$, waarvan het horizontale been niet na de ombuiging weder opwaarts gaat, zooals te Tjanggal het geval is, en welk teeken zich daarenboven door zijn „nail-head" onderscheidt. Meer komt zij overeen met de eenige $r a$ van Toek Mas.

Dit verschil van de $r a$ maakt het mij onmogelijk om aan een voor de hand liggende mogelijkheid te denken, namelijk aan een overblijfsel van Sañjaya's beweerde verovering van Oost-Java.

Aan den anderen kant maken de ,nail-heads” een nauwen samenhang met de oudste inscripties hoogst onwaarschijnlijk, zoo niet onmogelijk. Ik zou dus willen voorstellen deze inscriptie toe te

1) P.O.D. deel I plaat 28 regel 2 eerste letterteeken; men lette ook op de krul vooraan de ga van regel 3 ( $\mathrm{Tji}$ Aroeteun); ibidem plaat 31 regel 1 eerste letterteeken (Djamboe). KERN, V.G. VII pag. 119 regel 4, eerste letterteeken (Tjanggal). Bij de laatste inscriptie is het gebruikelijke teeken echter niet voorzien van een krul aan het voorbeen.

2) Zie Bijdragen 74 pag. 232 plaat $\mathrm{C}$ regel 7 , waar de ondergeschreven $p a$ geen knik vertoont, en ibidem plaat $\mathrm{A}, \mathrm{B}, \mathrm{C}$ passim voor de $w a$ zonder gebogen basis. 
schrijven aan de werkzaamheid van lieden, die zich vóór 760 op Oost-Java bevonden en wier schriftsoort sterke overeenkomsten vertoonde met dat van de Tjanggal-inscriptie uit 732 en van Toek Mas uit \pm 650 , kortom uit de 8 e of 7 e eeuw, den tijd, waarin Midden-Java voor het eerst in de buitenwereld bekend werd ${ }^{1}$ ).

Het valt zeer te betreuren, dat de steller van onze inscriptie niet wat breedsprakiger geweest is en zich heeft beperkt tot een voor een hinduistisch geleerde ontoelaatbare kortheid en kernachtigheid van uitdrukking. Anders ware het ons misschien gegeven geweest de dateering nauwkeuriger te stellen dan thans het geval moet zijn. Merkwaardig en belangrijk blijft onze inscriptie mijns inziens niettemin.

\section{XLVII.}

\section{De Batoe pělambean bij Karang bajat.}

In het derde deel van den Inventaris komt onder No. 2520 het volgende voor:

„Op een plek genaamd ,Pengapitan” van de padoekoehan Tjongapan een groot steenblok met inscriptie (elf kwadraat-letters en relief) ${ }^{2}{ }^{2}$ ), terwijl een literatuur-verwijzing naar Knebel's beschrijving ons het volgende leert:

„Beschreven steen. Op 7 paal afstands van de spoor-halte Soemberbaroe, in de wildernis van Tjongapan (men vergete de afschuwelijke wandeling), steekt een geweldig steenblok $1.45 \mathrm{M}$. hoog uit den grond. Op de ruwe zijde van het ruwe voorvlak is en-relief eene inscriptie van elf kwadraat-letters gebeiteld, en rechts daarvan, op een schuin-weggekapt nevenvlak, eveneens eenige letterfiguren, enrelief schuin naar beneden gebeiteld. Gedeeltelijk verweerd. Mij is van een en ander een afdruk toegezegd. Aan de linkerzijde is een gedeelte van den steen rechthoekig weggekapt, en in het nieuw-ontstaan bovenvlak uitgehold. In de uitholling is een langwerpig vierkant uitgespaard, met een gat er in; aan de andere zijde van het bekken nog een rond gat. Dat opstaand langwerpig vierkant staat in verband met een rechthoekige inkeping. Een en ander diende, volgens de

1) Wil men de vele ouderwetsche eigenaardigheden tot hun recht laten komen, dan dient men de inscriptie dus vóór de beide genoemde en aan den aanvang der bedoelde periode te stellen: \pm 600 . - Voor Toek Mas zie KERN V.G. VII : 203.

2) Inventaris III pag. 114 (O.R. 1923). 
desalegende, om olie te maken, en vandaar heeft de plek den naam gekregen van Pegapitan (plampejan)" ${ }^{1}$ ).

Ten slotte vermeldt de Inventaris dan weder, dat de beloofde afdruk nooit ontvangen werd ${ }^{2}$ ).

Deze merkwaardige steen maakte mijn belangstelling gaande, zoodat ik besloot, zoodra ik daartoe in de gelegenheid zou zijn, de ,afschuwelijke wandeling" als een noodzakelijk kwaad te aanvaarden, hopende, dat in de sinds Knebel's inventarisatie verloopen dertig jaren wel zooveel ter plaatse veranderd zou zijn, dat zij belangrijk zou kunnen worden ingekort. Dit laatste bleek dan ook het geval te zijn, en een wandeling van een paar paal vanuit de desa Karang bajat bracht mij door de sawahs op de bewuste plek, die thans niet meer in de wildernis, doch aan den rand van de wildernis (het oerbosch op de zuidelijke Janghelling) gelegen is ${ }^{3}$ ).

Een nauwkeurige bezichtiging van den steen, die thans rondom door sawahs is omgeven, bleek al dadelijk correcties op Knebel's beschrijving te kunnen geven.

In de eerste plaats telt de horizontale inscriptie niet elf, doch twaalf letterteekens ${ }^{4}$ ). In de tweede plaats zijn de letterteekens, welke rechts daarvan zijn aangebracht, niet schuins naar beneden, doch, zooals te verwachten viel, schuins naar boven aangebracht, zooals men dat wel op spiegelhandvaten aantreft.

In de derde plaats bleek echter Knebel's beschrijving van het uiterlijk van den steen zoo weinig duidelijk te zijn, dat men zich daaruit onmogelijk een betrouwbare voorstelling zou kunnen maken van hetgeen de werkelijkheid te zien geeft. Dit is echter niet uitsluitend aan Knebel's beschrijving te wijten, aangezien door het ingrijpen der beeldhouwers in den oorspronkelijken, natuurlijken vorm van het rotsblok (dat

1) O.R. 1904: 139.

2) O.R. 1923: 114 .

3) Voor hen, die den steen wenschen te bezoeken, diene het volgende. Men kan per automobiel vanuit Pringga wirahan (ten W. van Tanggoel) de desa Karang bajat bereiken, waarna men nog tot de eerstvolgende scherpe bocht door kan rijden. Van hieruit gaat men noordoostwaarts door de sawahs naar de doekoeh Tjongapan en steekt benoorden deze doekoeh de kali Karang bajat over langs een pinangstam. Daarna volgt men de kali stroomopwaarts door de aangrenzende sawahs tot ongeveer aan den rand van het oerbosch. Daar ter plaatse echter zeer vele lahar-keien liggen, is het gewenscht iemand uit de doekoeh Tjongapan of uit Karang bajat mede te nemen. In den drogen tijd, vooral als de sawahs droog staan, is de tocht zeer goed in ruim een uur tijds te volbrengen.

4) Het is duidelijk, dat Knebel de wisarga met het daarop volgende teeken voor de $s a$ heeft bijeengenomen. 


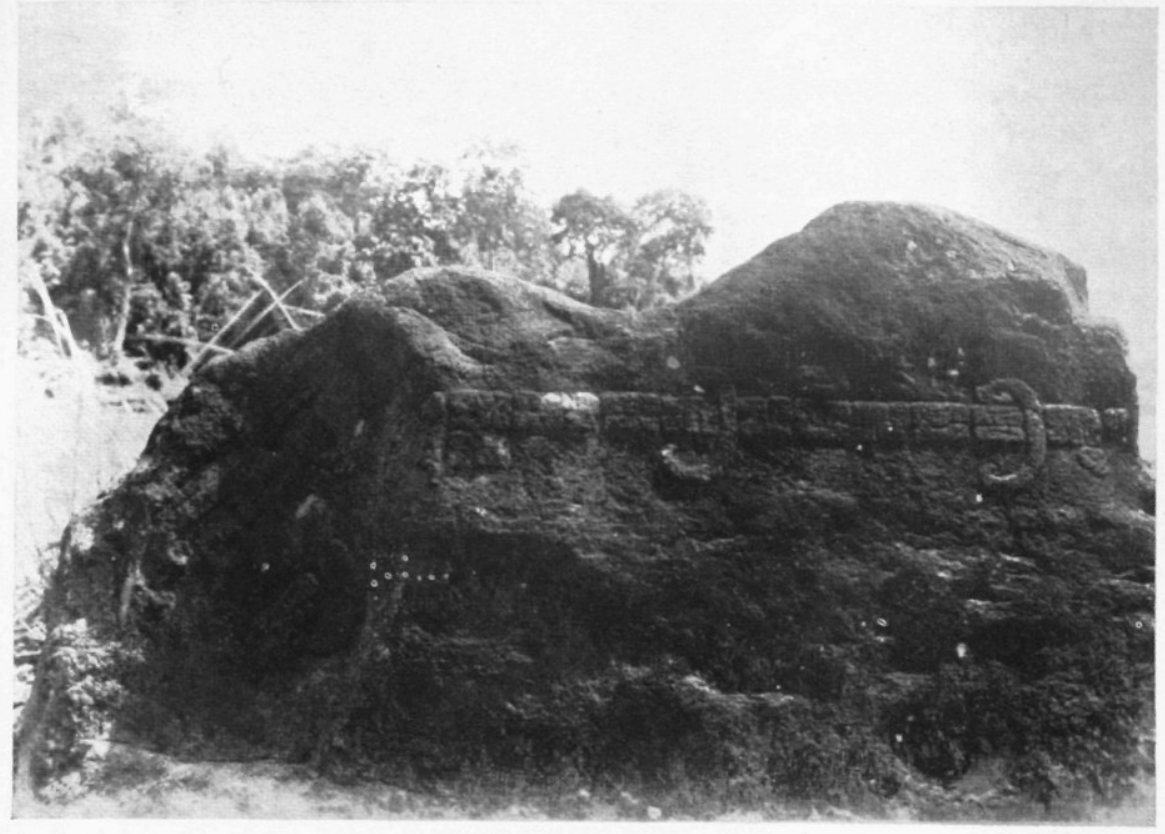

Figuur 3. De Batoe pělambean bị Karang Bajat (Djĕmběr).

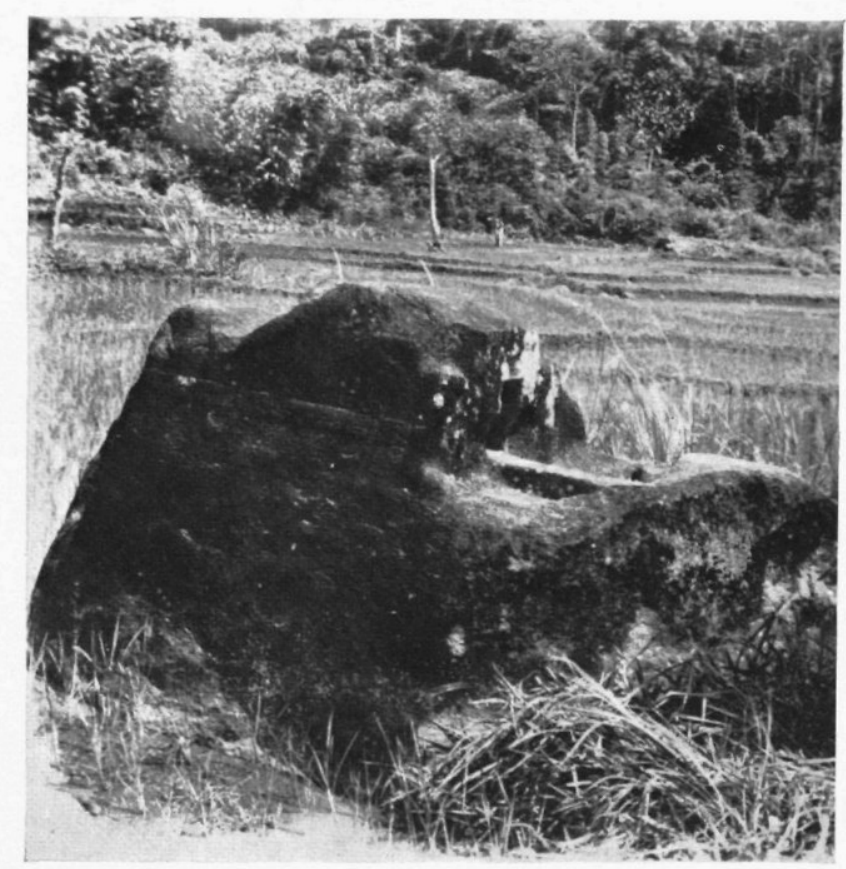

Figuur 4. Zij-aanzicht van den Batoe pělambean. 
overigens niet "geweldig" is) zoovele nieuwe vlakken en vlakjes zijn ontstaan, dat slechts een foto van een en ander verduidelijkend kan werken,

Zulk een foto geef ik dan ook hier ter verduidelijking van de beschrijving, hoewel de witte schimmels het juiste beloop der vlakken op sommige plaatsen onduidelijk maken.

Alvorens nu nog even stil te staan bij de mogelijke bestemming van een en ander, wil ik de inscriptie bespreken.

Zij bestaat, zooals reeds opgemerkt werd, uit twee gedeelten.

Een daarvan is de horizontale inscriptie van twaalf letterteekens (twee pada's en twee paten's niet medegeteld), de andere een verticale inscriptie, rechts van de eerste aangebracht, zoodat zij zich daarvóór bevindt.

De horizontale inscriptie luidt naar mijne lezing : tlah sanak pangilanganku.

De verticale inscriptie luidt: sarzewa hana.

De beteekenis van geen van beide inscripties is geheel duidelijk, hetgeen ons niet verwonderen kan, aangezien dergelijke korte opschriften, zooals ze ook op spiegelhandgrepen en ringen wel voorkomen, nog nimmer bevredigend verklaard konden worden, hetgeen wel moet worden toegeschreven aan een opzettelijke bedoeling van den maker. Immers, de meeste van dergelijke opschriften zijn gesteld in het zoogenaamde kadiri-schrift en vele dateeren dan ook werkelijk uit de kadirische periode. $\mathrm{Nu}$ is deze periode bekend om hare voorliefde voor het kāwya, het kunstdicht, welk literatuur-genre gepaard gaat aan het maken van kleinere spreuken en kernachtige gezegden, welke hun inhoud slechts prijs dienen te geven aan hen, die voorzien zijn van een buitengewone kennis van de schoone letteren. Een overblijfsel daarvan vinden wij in de zoogenaamde sĕngkalan's, welke eveneens eer dienen om het bedoelde jaartal te verbergen dan dit openlijk mede te deelen. Zoozeer werd zulks tot een bewust doel, dat men, in gevallen, dat het jaartal toch ook gelezen diende te worden, dit ten overvloede in cijfers daarnaast plaatste. Zoo verbaast het ons dan ook niet, dat ons opschrift niet bij den eersten oogopslag zijn geheim prijsgeeft ${ }^{1}$ ).

1) Op deze neiging is reeds herhaaldelijk gewezen. Zie hiervoor nog BERG in zijn "Inleiding tot de studie van het Oud-Javaansch" pag. 46 vlgg. Nog immer beleeft de geletterde Javaan meer genoegen van een duistere, voor velerlei uitleg vatbare en aan individueele opvattingen ruimte latende plaats dan van een ,unzweideutige” mededeeling. 
Dat de twee opschriften aanéén gelezen dienen te worden, lijkt mij onwaarschijnlijk. Het gebruik der pada's aan het begin en einde van het horizontale opschrift pleit daartegen, zoodat wij het korte opschrift zullen moeten opvatten als iets op zichzelf staands. Wat dan echter de beteekenis kan zijn van dit „Alles is er” of „Allen zijn er”, ontgaat mij. Tenzij hier sarwa een der namen van Çiwa moet aangeven (çarwa) en het geheel zooveel zeggen wil als : „Çiwa is” ${ }^{1}$ ). Het tweede gedeelte zou letterlijk beteekenen: „Verlost (is de) vriend (of: broeder), mijn bevrijdingsmiddel.", indien wij althans aan tlah de beteekenis van wināça mogen hechten, welke van der Tuuk bij matlahang opgeeft ${ }^{2}$ ). Nemen wij aan, dat de steen vroeger toch wel in het woud moet hebben gelegen en dat dus de maker der inscriptie zeer goed een kluizenaar kan geweest zijn, dan zou een en ander kunnen zijn vervaardigd naar aanleiding van den dood (de verlossing) van des kluizenaars broeder of vriend, die tevens zijn guru was en hem den weg tot verlossing had gewezen. Dat deze verklaring echter niet meer dan een gissing is, is duidelijk ${ }^{3}$ ).

Hoewel wij zouden vermoeden, dat ook hier een sĕngkalan een bepaald jaar verborgen houdt, is het mij toch niet mogen gelukken er een uit de gegeven begrippen samen te stellen. Om den approximatieven datum te weten te komen dienen wij ons dus tot de gebruikte schriftsoort te wenden.

Een nadere dateering binnen de grenzen van het zoogenaamde kadirische schrift lijkt mij geen onmogelijkheid. Als algemeen criterium kan daarbij aangenomen worden, dat de oudste vertegenwoordigers van genoemde schriftsoort zich onderscheiden van de jongere door een grootere strengheid van vormen, terwijl omgekeerd de jongere in sterke mate de neiging bezitten hunne vormen door krulwerk op te smukken.

Deze neiging kan men gemakkelijk constateeren door onderlinge vergelijking van het schrift van Djala toenda uit 977, van Poeh Sarang uit 1002, van de oorkonden G.P. 1 en 2 van den Goenoeng Panoelisan op Bali uit 1011 en het Goenoeng-Kawi-schrift, dat in eenigszins gewijzigden vorm ook voorkomt op den Goenoeng $\mathrm{Pa}-$

1) Of: Ç. zij. Bevreemdend blijft dan toch het feit, dat dit sarzwzva niet door een of ander epitheton ornans voorafgegaan wordt, tenzij het de bedoeling was ook hier wederom een woordspeling te doen plaats hebben.

2) Zie voor deze opvatting Oudheidkundige Aanteekening I in Bijdragen 1929: 479 vlgg.

3) Ik wijs in dat geval op de niet geheel correcte spelling van sanak i.pl.v. sānak en pangilangan i.pl.v. panghilangan. 
noelisan en elders, en dat op de tweede helft der 11e eeuw gesteld moet worden $\left.( \pm 1075)^{1}\right)$.

$\mathrm{Er}$ is echter nog een ander kenmerk, dat ons eenigszins den weg kan wijzen. Ik bedoel de wijze, waarop de voorzijde der letterteekens is behandeld.

In de oudste exemplaren vinden wij slechts de verdikking van de bij het gebruikelijke schrift bestaande lijnen tot banden, waarbij dus aan de voorzijde (voorste been) van elk teeken de kop een weinig uitsteekt. Later heeft men, door de neiging het letterteeken zoo volmaakt mogelijk in een rechthoek te componeeren, dezen uitstekenden kop als iets onevenwichtigs gevoeld en voorzien van een tegenhanger onderaan het voorste been, welke het evenwicht weer herstelde. Tusschen beide bevond zich dan een hoekige inkeping, die de neiging vertoont kleiner te worden. Ten slotte zijn dan ook de kop en het onderste uitsteeksel zoover uitgegroeid en elkaar genaderd, dat er niet meer van een inkeping, doch van een streep tusschen beide gesproken kan worden. Dit laatste is zelfs doorloopend het geval bij de kadirische schriftsoorten van Bali uit het einde van de 1le eeuw; bedoelde streep is dan meestal voorzien van een daar rechthoekig op staand streepje, dat zich nogmaals rechthoekig ombuigt, zoodat het geheel een meanderfiguurtje wordt, dat, indien het wat groot is uitgevallen, vaak de lezing van het teeken in hooge mate bemoeilijkt.

Hoe ziet ons schrift er nu uit?

In de eerste plaats valt het op, dat de teekens niet meer die strengheid van vormen vertoonen, welke tot de oudste periode behoort. Doch evenmin maken zij een krullerigen indruk of zijn zij door in de letterteekens aangebrachte krulletjes en boogjes rijkelijk verfraaid. Belangrijk is het echter te zien, dat de meeste teekens aan den voorkant van het voorste been een tamelijk wijde inkeping hebben in de plaats van een nauwe streep. Ik zou dan ook op grond hiervan geneigd zijn de schriftsoort te plaatsen tusschen de balische latere groep uit de $2 \mathrm{e}$ helft der $11 \mathrm{e}$ eeuw en de oudere javaansche exemplaren, met andere woorden omstreeks 1050 A.D. Zuiver is deze nadere dateering natuurlijk nog niet, en kan zij ook niet zijn, gezien het nog geringe aantal gedateerde inscripties in deze schriftsoort,

1) Afbeeldingen respectievelijk in O.V. 1921: 78 fig. 1 en 2, en O.V. 1921: 148 fig. 4 (Djala toeṇda); Kern V.G. VII : 80 (Poeh Sarang); Oudheden van Bali I: Platen: fig. 108, 109 (G.P. 1 en 2); ibidem 110, 111, 112 (G.P. 4, inscr. w en $\mathrm{x}$ ) en O.V. 1921: 60 fig. 8 (Goenoeng kawi). 
doch als benadering durf ik haar toch wel te geven. In ieder geval kan zij voorloopig als werkhypothese gelden.

Ten slotte nog een kort woord over den eigenaardigen vorm van een gedeelte van den steen.

Voorloopig blijft het voor mij een raadsel, wat de bestemming van een en ander kan geweest zijn. Wel wil ik er de aandacht op vestigen, dat de opstaande wand op een eigenaardige wijze is bijgewerkt geworden, hetgeen op de foto door de schimmels niet tot zijn recht komt. Bevindt men zich recht voor dit gedeelte, dan maakt deze afvlakking den indruk van een olifantskop, welke vlak vóór de ooren glad is afgesneden. Het zou dan niet onmogelijk zijn, dat oorspronkelijk het uitstekende deel van den kop door middel van een dook in de inkeping was gelaten en op zijn beurt de doorboorde ,brug” in een inkeping opnam ter voorkoming van verschuiving van dit afzonderlijk aangebrachte gedeelte. Mogelijk is daarbij opneming van de asch van den gestorven goeroe in de casementen het doel geweest en was de steen tevens een ,tjandi”". Wat dan echter de beide gaten te beteekenen hebben en hoe het beloop van dien kop moet geweest zijn, is mij allerminst duidelijk, zoodat ik een en ander voor niet meer dan een indruk geef.

De naam kan ons ook al niet op weg helpen, ook al nemen wij in de plaats van Knebel's pĕlampejan het pé̀lambean, dat ik te hooren kreeg. Lambe is een lip of rand en kan zoowel van menschen als van dieren en voorwerpen gezegd worden. Hoe Knebel er toe kwam dit met olie te verbinden, is mij niet erg duidelijk; het olie-verhaal werd mij niet verteld $^{1}$ ).

\section{XLVIII.}

\section{Waar lag Erlangga's kluizenarij van den Pucangan?}

Het is van algemeene bekendheid, dat de zoogenaamde Calcuttaoorkonde de schenking van rechten bevat aan de desa's Pucangan, Barahĕm en Basuri ten behoeve van de kluizenarij van Pucangan,

1) Nemen wij voor een oogenblik aan, dat pĕlambean met lambe, lip of rand, samenhangt, dan zou Batoe pělambean zooveel kunnen beteekenen als „steen met de randen” of „steen, waarmede of waarop lambe's gemaakt worden". Dat het woord met lembeh zou samenhangen, lijkt mij niet erg waarschijnlijk; in ieder geval geeft dat nog minder beteekenis. Ten slotte wijst Prof. Berg mij op de vertaling ,steen van den rand (van de wildernis)”. 
welke gesticht was ingevolge een in verband met Erlangga's krijgsbedrijven gedane gelofte. Erlangga zelf is dan ook de schenker. Thans verblijft die oorkonde in het museum te Calcutta; vandaar de naam ${ }^{1}$ ).

De herkomst van dezen oorkonde-steen is onbekend, hoewel aangenomen kan worden, dat hij uit de residentie Soerabaja afkomstig is. Door deze onbekendheid met de oorspronkelijke vindplaats heeft men dan ook de bedoelde kluizenarij niet kunnen terugvinden en zijn toevlucht moeten nemen tot een hypothese om tenminste ongeveer het oord van herkomst te begrenzen. In de eerste plaats heeft men daarbij gedacht aan een berg, afgaande op het pārçwe pügazwato girer van de Sanskrit-zijde der oorkonde, hoewel de Kawi-zijde slechts spreekt van gronden te (of van) Pucangan, Barahĕm, Basuri ${ }^{2}$ ).

Hierop voortbouwende heeft Rouffaer een hypothese opgeworpen aangaande de juiste ligging van dien berg ${ }^{3}$ ). In de eerste plaats was die berg te verwachten nabij de Brantas-vlakte, waar Erlangga blijkens zijn oorkonden heerschte. In de tweede plaats kon men er wellicht denzelfden berg in zien, waar zijn vader Udayana bijgezet was in de badplaats Djala toeṇda, dus den Pĕnanggoengan. In de derde plaats zijn er verschillende andere oudheden op de hellingen van dien berg gevonden. En ten slotte vernam Rouffaer van den heer Moquette, dat er aan de lagere hellingen van den Pĕnanggoengan (evenals trouwens in de dalen van het geheele Wĕlirang-Ardjoena-complex) talrijke wilde pinangpalmen voorkwamen. Dit laatste, gevoegd bij de wetenschap, dat pügarwat zooveel als „rijk aan betelpalmen” beteekent, en dat kĕpoetjangan in jongere javaansche teksten als ,pinangpalmberg” voorkomt, brengt Rouffaer tot de conclusie: „Voorloopig mag dus met voldoenden grond vermoed worden, dat de berg Poetjangan alias Pūgawat van Vorst Erlangga de Pěnanggoengan is".

Ik geloof echter, dat het thans tijd is, het voorloopig karakter van deze conclusie op den voorgrond stellende, haar door een meer definitieve te vervangen.

Immers, sinds wij weten, dat de naam Udayana, voorkomende op de ruine van de badplaats Djala toeṇda, naar alle waarschijnlijkheid niets met Erlangga's vader te maken heeft (zoo het al iets anders is dan de naam van den held uit het reliefverhaal), is het voor-

1) Uitgegeven door KeRN in V.G. VII pag. 83 vlgg. Zie ook O.J.O. LXII. De oorkonde is uit 1041 A.D.

2) Respectievelijk vers 32 en regel 37.

3) In N.B.G. 1909 pag. 180 vlgg. 
naamste argument pro vervallen ${ }^{1}$ ). Men zal het mij toch ten goede houden, indien ik uit het voorkomen van wilde pinangs op den Pĕnanggoengan van 1909 geen conclusies wil trekken ten opzichte van Erlangga's kluizenarij uit 1041, en men zal dit zonder bezwaren willen doen, indien men zich realiseert, dat de wilde pinang in den geheelen Archipel voorkomt, behalve in de hoogere bergstreken. Aan het voorkomen van deze areca-soort eenigerlei conclusies te verbinden ten opzichte van de ligging van een berg Pucangan is hetzelfde als Ayam Wuruk's in de Nāgarakrtāgama beschreven hertenjacht te localiseeren op het Jang-plateau, omdat zich daar thans 20.000 herten bevinden.

Geen der door Rouffaer opgegeven redenen kan er ons dan ook meer toe brengen met uitsluiting van alle andere bergen de kluizenarij van Pucangan op den Pěnanggoengan te zoeken.

Intusschen is het Rouffaer en anderen ontgaan, dat er zich bij de Brantas-delta een berg bevindt, die den naam Poetjangan draagt $\left.{ }^{2}\right)$. Het is de 167 meter hooge, in het Kĕṇ̣enng-massief gelegen, onder het district Plasa der residentie Soerabaja ressorteerende kalksteenberg, welke zich ten Noord-Westen van Majapahit aan de overzijde van den Brantas verhief en vanuit die plaats bij helder weer zichtbaar moet geweest zijn.

Is deze identificatie door de naamsovereenkomst al heel wat steekhoudender dan die met den Pĕnanggoengan, thans dienen wij ons de vraag voor te leggen, wat er nog gevonden kan worden, dat de identificatie van Poetjangan met Pucangan waarschijnlijker kan maken.

In de eerste plaats moet $\mathrm{ik}$ er dan de aandacht op vestigen, dat die andere kluizenarij van Erlangga, de çrīwijayāçrama, zich $71 / 2 \mathrm{~km}$ zuiver ten Oosten van den Poetjangan-top in hetzelfde gebergte moet hebben bevonden, daar wij in de desa Troeneng den naam herkennen van het Turun hyang, dat in de stichtingsoorkonde van deze kluizenarij zijn gronden tot onderhoud van de kluizenarij moest afstaan. De oorkonde zelf is daarenboven in genoemde desa gevonden ${ }^{3}$ ).

Dan vestig ik er de aandacht op, dat niet minder dan drie oor-

1) Zie mijn opmerkingen in Oudheidkundige Aanteekening I (Bijdragen 85 (1929) : 479 vlgg.).

2) Op het blad Oost-Java van den grooten atlas van den Topographischen Dienst wordt deze naam zelfs voor het geheele gebergte gebezigd; op detailblad LVIII A van de topographische kaart $1: 50.000$ is het de naam van een der vele toppen.

3) O.J.O. LXIV. 
konden van Erlangga (helaas nimmer uitgegeven) gevonden zijn in eenige desa's, gelegen aan den voet van genoemden Poetjangan, nl. die van Soembĕr goerit, Kĕtěmas en Grogol ${ }^{1}$ ).

Ten slotte breng ik in herinnering, dat er van de, naar mijn weten een zeventiental tellende, bekende oorkonden van Erlangga vier van onbekende herkomst zijn en alle dertien overige gevonden zijn in de streek ten Noorden van den Brantas; is de door mij voorgestelde identificatie juist, dan is dus ook nummer veertien uit die streek afkomstig.

Van onbekende herkomst zijn dan nog slechts die van Cane, van Pātakan en van Baru ${ }^{2}$ ). Mocht de laatste naam overeenkomen met het huidige Sima waroe (ten Z.O. van den Poetjangan benoorden den Brantas), dan blijven er nog slechts twee over ${ }^{3}$ ).

Zonder dus te kunnen zeggen, dat Erlangga's grondschenkingen zich tot de streek benoorden den Brantas hebben beperkt, ligt in het bovengezegde naar mijn meening toch voldoende grond om bij het zoeken naar den Pucangan in de eerste plaats te denken aan dien Poetjangan bij Plasa, waar het bij wijze van spreken van Erlangga's oorkonden heeft gewemeld.

Het is verleidelijk aan het bovenstaande nog andere gevolgtrekkingen te verbinden, doch slechts de uitgave der nog onuitgegeven oorkonden van Erlangga (in totaal niet minder dan 8 van de 17!) kan ons daarbij van den noodigen steun voorzien. Zoo doet het feit, dat alle oorkonden van dien vorst, waarvan de herkomst bekend is, afkomstig zijn uit de streek benoorden den Brantas - volgens mijn elders uiteengezette opvatting dus het oorspronkelijke Daha of Pañjalu ${ }^{4}$ ) —, de vraag opkomen, of wij dan toch in het Wwatan mās, dat volgens een zijner oorkonden zijn residentie was, niet een aan de kali Mas gelegen plaats dienen te zien. Ook dienen wij te onderzoeken, in hoeverre het in de javaansche tradities zulk een groote rol spelende rijk Pagěr wěsi of Giling wěsi zou kunnen samenhangen met dien vlak ten N.O. van den Poetjangan gelegen berg Radjĕg wěsi. Dit alles echter tot later uitstellende, kunnen wij als voorloopige winst boeken het feit, dat wij achter de beschrijvingen van den door

1) Inventaris II no. 1781, 1782 en 1781. O.R. 1907: 126 vlg.

2) Respectievelijk O.J.O. LVIII, LIX en LX.

3) Detailblad 1:50.000 No. LVIII B (spoeddruk) $\pm 11 / 2 \mathrm{~km}$ benoorden den Brantas (westzijde van het blad). In deze streek komen meerdere plaatsnamen met sima samengesteld voor; ook sima alleen. Sima waroe beteekent dan zooveel als "Het stift te (van) Waroe (Baru)".

$\left.{ }^{4}\right)$ Oudheidkundige Aanteekening XVIII (Bijdragen 89 (1932): 101 vlgg.). 
Kern's uitgave beroemd geworden Calcutta-steen kunnen voegen: „Misschien afkomstig van de helling van den Poetjangan, district Plasa, afdeeling Djombang, residentie Soerabaja" ${ }^{1}$ ).

\section{XLIX.}

\section{Het rijk Gadjah-Mada $\left.{ }^{2}\right)$.}

Een der nog immer op een bevredigende oplossing wachtende vraagstukken uit de javaansche geschiedenis is dat van het bestaan van een rijk „Gadjah-Mada” genaamd. Zooals men weet, zou dit een bij Malang gelegen rijk zijn geweest, hetwelk in de javaansche tradities een rol speelt en, nadat het in of omtrent 1639 door Soeltan Agoeng zou zijn veroverd, de mataramsche hoven zou hebben voorzien van de zoogenaamde Gadjah-mati's, een ambtenarenstand, over

1) Naar Dr. Bosch mij schreef, had deze eveneens aan den Poetjangan gedacht als plaats van Erlangga's kluizenarij, doch deze gedachte laten varen op grond van de onaanzienlijkheid van dezen berg. Naar het mij voorkomt, dient men echter aan het pügawat van de Sanskrit-zijde der Calcutta-oorkonde geen beschrijvende beteekenis te hechten; het feit, dat Erlangga dezen berg tot zijn verblijfplaats koos, was reeds voldoende om den berg met dit epitheton aan te duiden. Ook vond Dr. Bosch er geen overblijfselen van beteekenis; geheel afgezocht is de streek echter nog niet, zoodat wij de hoop nog niet mogen opgeven eenmaal - zij het ook geringe - sporen van Erlangga's kluis terug te kunnen vinden.

$\mathrm{Na}$ het afsluiten van den tekst ontving ik bericht van den AssistentWedana van Koedoe (Plasa, Djombang), dat er zich op den Poetjangan twee graven bevinden, waarvan er een met een „tjoengkoeb” van hout is gedekt en in den reuk van groote heiligheid staat. Ofschoon men weet, dat er geen persoon van mohammedaanschen godsdienst is begraven, pleegt men er het bekende „njadran” te verrichten. Bij navraag bleek mijn zegsman, dat men dit graf beschouwde als het graf van Dewi Kili Soetji. Nu behoef ik er hier zeker niet aan te herinneren, dat deze persoon de kluizenarende dochter is van Erlangga. Waar wij reden hebben te veronderstellen, dat de gezochte kluizenarij van den Poetjangan door Erlangga ten behoeve van diens dochter zou zijn gesticht, meen ik, dat er thans wel geen reden meer gevonden kan worden deze kluizenarij elders te zoeken dan op den berg Poetjangan bij Plasa. Mijn zegsman rapporteerde mij voorts de overblijfselen van een muur uit roode zoogenaamde Madjapahit-brikken, welke door de bevolking als afkomstig van widadari's worden beschouwd.

2) $\mathrm{Bij}$ het schrijven van aanteekening $\mathrm{N}^{0}$. XLIX was het mij ontgaan, dat Rouffaer in een zijner niet opgenomen Encyclopaedie-artikelen reeds op de waarschijnlijkheid wees, dat het Rijk Gajah-Mada uit de apanage van Gajah Mada zoude zijn ontstaan. Hoewel wat dat betreft deze aanteekening dus in de pen had kunnen blijven, publiceer ik haar toch om de gegeven details, die, naar ik meen, Rouffaer's gissing aannemelijker kunnen maken dan zij op het eerste gezicht mag lijken (zie deze Bijdragen 86: 202 vlgg.). 
welks beteekenis in het tijdschrift Djawa uitvoerige mededeelingen zijn verschenen ${ }^{\mathbf{1}}$ ). De oorsprong van dit rijk ligt echter geheel in het duister, en als eenig betrouwbaar feit kennen wij het bericht van Pigafetta, dat aldus luidt :

„...en Java Major (deze volken noemen haar niet Java, maar Jawa); de grootste steden zijn in Java [en] zijn deze: Madjapahit (dier koning, toen hij leefde, was de grootste van al deze eilanden en heette radja Pati Oenoes), Soenda (in deze groeit veel peper), Daha, Děmak, Gadjahmada, Měntaraman ${ }^{2}$ ), Djapara, Sidajoe, Toeban, Grěsik, Soerabaja en Bali ; enz." ${ }^{3}$ ).

Waar dit bericht op in 1522 in Timor ingewonnen berichten berust, mogen wij dus aannemen, dat in dat jaar een rijk, genoemd met den naam van Majapahit's grootsten patih, niet alleen bestaan moet hebben, doch ook tot de voornaamste van Java moet behoord hebben. Wij zullen wel niet mogen denken aan een ,stad”, waartoe Pigafetta's mededeeling ,,de grootste steden zijn in Java” aanleiding zou kunnen geven, en zooals Veth o.a. meent, als hij zegt : „Pigafetta noemt Gadjah mada onder de steden van Java”. Immers, de mededeeling, dat in Soeṇda veel peper groeit, slaat zeker niet op een stad, zoodat wij mogen aannemen, dat Pigafetta hoofdstad en rijk in sommige gevallen heeft vereenzelvigd.

De javaansche tradities nu brengen het ontstaan van dit rijk, aan welks bestaan wij wel niet mogen twijfelen, in verband met den reeds genoemden patih Gajah Mada, die gevlucht zou zijn na den val van Majapahit en in Sĕnggara (in de buurt van Kĕpandjen, in het zuidelijk gedeelte van de Malangsche vlakte) een onderkomen

1) Zie Veth, Java ${ }^{1}$ deel II: 213. Voor de Gajah-mati's zie Djawa II: 215 vlgg.

2) De identificatie van Minutarangan met Měntaraman (= Mataram) lijkt mij nog niet zoo zeker als Rouffaer meende. Zou toch in dat geval Mataram in 1522 onder de grootste of belangrijkste steden (lees: streken) van Java geteld hebben, hetgeen, met het oog op wat wij van elders weten, niet te verwachten valt. Immers, Mataram is eerst in de tweede helft van de $16 \mathrm{e}$ eeuw op den voorgrond getreden en dat nog op zeer bescheiden wijze. Welke streek dan echter wel bedoeld zou zijn, ontgaat mij. Kan er Tangaran in schuilen ?

3) RoufFAER in Bijdragen 50 (1899) pag. 131 vlgg., alwaar ook de italiaansche tekst in twee redacties wordt gegeven. Het „le magiori ville sono in Iava sorino queste:" moet natuurlijk gelezen worden „le magiori ville sono in Iava; sono queste :”. Dat nu eens van „ville”, dan weer van „ysolle” gesproken wordt, zal wel zijn oorsprong hebben in het feit, dat men toenmaals elk rijk ook als een afzonderlijk eiland beschouwde, onderling gescheiden door engten of kreeken, welke ten rechte rivieren waren, die men echter nog niet had verkend. 
vond. Diens zoon verplaatste de kraton naar het Oosten en breidde het rijk uit over het geheele gebied van het voormalige Singhasāri, welks naam in Soepit Oerang gewijzigd werd. Aan hem wordt de Malangsche oude vesting Koeța Bĕḍah, waarvan resten werden gevonden, toegeschreven, en vanuit deze versterking zou hij dan zooveel mogelijk schade hebben trachten te berokkenen aan de zaak der muslimsche machthebbers aan de noordkust. Volgens sommige overleveringen zou zijn rijk reeds kort na den val van Majapahit door Dĕmak zijn veroverd, volgens andere eerst door Soeltan Agoeng in 1639 zijn ten onder gebracht, waarna dan de instelling der zgn. Gadjahmati's in de mataramsche kraton volgde.

Het is zonder twijfel aan het feit, dat slechts latere javaansche overleveringen ons omtrent de lotgevallen van dat rijk inlichten, te danken, dat Krom er zich verder niet over uitlaat ${ }^{1}$ ). Hij volstaat met het citeeren van gemeld bericht van Pigafetta, waaruit de lezer omtrent het bestaan van dat rijk wordt ingelicht, doch onthoudt zich van pogingen om het voorkomen van dien naam in dat bericht te verklaren. Wij komen dus niet te weten, of hij aan het bestaan er van geloof hecht, of dat hij van meening is, dat wij met een legende te maken hebben ${ }^{2}$ ). Ook omtrent een mogelijk verband tusschen den naam van dat rijk en dien van den patih van Majapahit spreekt hij zich niet nader uit. Toch meen ik, dat daarmede niet goed volstaan kan worden, ook al zou men de latere berichten uit de javaansche overleveringen voor pure fantasie willen verslijten. Er is namelijk iets op te merken, dat, als ik mij niet vergis, wel degelijk eenig verband kan leggen tusschen dit rijk en de figuur van Gajah Mada, ook al is het niet veel meer dan het openen van een mogelijkheid. Daar echter maar al te vaak werd bewezen, dat het vestigen van de aandacht op een mogelijke oplossing van een probleem de werkelijke oplossing daarvan niet zelden uitlokt, meen ik goed te doen hier aldus te handelen.

Wat is namelijk het geval ?

In zang 19 van de Nāgarakṛtāgama lezen wij het volgende:

wwantěn dharma kasogatan prakaçite madakaripura kastaweng langö/ sīmānugraha bhūpatī sang apatih gaja mada racananya nuttama/ yekānung dinunung nareçwara pasanggrahan ira piněnĕd rinūpaka/

1) Кrom, Geschiedenis 2 : 460.

2) Waartoe minder de naam van het rijk dan wel de aan Rājasanagara's patih toegedichte stichting aanleiding zou kunnen geven (zie beneden). Deze leefde immers bijna tweehonderd jaren vóór bedoelden val. 
andondok mahawan rikang trasungay andyusi capahan

atīrthaçewana $/ / 2 / /$

d.i. Er is een buddhistisch heiligdom (Kern: stift) bekend als Madakaripura, vermaard om [zijn] bekoorlijkheid (Kern: schoonheid); het is een vrij stuk grond, een gunstbewijs (Kern: schenking) van den Vorst aan den Heer Rijksbestuurder. De aanleg (Kern : het bouwwerk) er van is onovertroffen. Daarheen begaf zich de vorst; zijn tijdelijk verblijf was fraai in orde gemaakt en van figuren voorzien (Kern: netjes gemaakt en versierd). Zijn doel was te gaan naar de bron (Kern : tijdelijk daar vertoevende ging hij enz.) om te baden in het bassin als tïrthayātra ${ }^{1}$ ).

Alvorens uit deze strophe de conclusie te trekken, welke ik op het oog heb, wil ik eerst de voornaamste afwijkingen mijner vertaling verantwoorden.

dharma. Kern vertaalt met ,stift”, hetgeen natuurlijk juist is, doch door het in regel 2 volgende sima zijn kracht verliest; dit laatste woord duidt immers het feit aan, dat de grond van de dharma van belastingen was vrijgesteld, zoodat in het gebruik van het woord dharma de nadruk op het godsdienstig karakter dient te vallen.

anugraha. Kern vertaalt met ,schenking”, hetgeen niet juist kan zijn; van schenking van den grond, die eigendom van de desa was, kan geen sprake geweest zijn, wel van het afstand doen van 's vorsten rechten op den grond, dus ,,gunstbewijs".

rinüpaka. Zie mijn opmerkingen dienaangaande in verband met zang $\left.11^{2}\right)$.

andondok. Met Poerbatjaraka lees ik andondon, dat ik echter als verbalen vorm van dondon, doel, zou willen opvatten. Voor diens vertaling van trasungay met ,rotsachtig" - moeten wij hem zoo begrijpen, dat hij mahawan met „paden” vertaalt ? - kan ik geen goeden grond vinden. De opvatting, dat tras-sungay zooveel als ,rivierhoofd”, dus ,bron” zou beteekenen, lijkt mij niet onmogelijk.

capahan. Kern's opvatting, dat wij hierbij aan de zoogenaamde oudjavaansche „badkuipen” moeten denken, is natuurlijk reeds achterhaald; dit zijn ten rechte sarcophagen geweest.

tīrthasewana. Het meer gebruikelijke woord is tīrthayātra, ,ritueel bezoek aan heilige (bad)plaatsen (bronnen)". Dit kent men in de Vorstenlanden nog.

1) Nāgarakṛtāgama, editic KERN-KROM pag. 68.

2) Oudheidkundige Aanteekening XXXIII (Bijdragen 90 (1933)).

D1. 95. 
Thans de beteekenis van ons citaat.

Zooals men ziet, heeft Rãjasanagara aan zijn patih Gajah Mada tijdens diens leven de vorstelijke rechten geschonken van een stuk grond, dat een dharma werd onder den naam Madakaripura. Reeds Kern wees nu op het feit, dat de naam Madakari precies hetzelfde beteekent als en een Sanskrit-omzetting is van Gajah Mada. Wij kunnen er nog op wijzen, dat het hier betreft een dubbele sanskritiseering. Immers, de titel Gajah is, hoewel Sanskrit, toch inheemsch van karakter, zoodat de combinatie Gajah Mada een zuiver inheemsche samenvoeging is van twee Sanskrit-woorden, nl. gaja en mada. In werkelijkheid beteekende de gansche naam waarschijnlijk niet "dolle olifant", doch Gajah (= patihstitel) van Mada (= een gebied). Thans corrigeert men een en ander in beter Sanskrit, nl. madagaja of madakarin $=$ een dolle olifant, hetgeen wellicht een woordspeling is, daar wij misschien mogen aannemen, dat het eerste lid van dien naam eigenlijk de naam is van een gebied Mada, waarnaar onze Gajah genoemd placht te worden. Hij heet ook wel $m p u$ mada, Heer (van) Mada ${ }^{1}$ ).

Het verband tusschen Gajah Mada en bedoelde dharma zou dan als volgt zijn: afkomstig van Mada of op een of andere wijze het heerschap daarover verkregen hebbende, verkreeg de patih van zijn vorst als gunstbewijs de algeheele beschikking over alle rechten van een bepaald deel van dat gebied en wel met het doel om daar zijn dharma te stichten, misschien zijn bijzettingsheiligdom, welks $t j a n d i$ dan na zijn dood uit die geschonken rechten zou kunnen worden onderhouden. Gajah Mada's tjaṇdi zouden wij dan in die streek moeten zoeken ${ }^{2}$ ).

Doch waar?

Hierover kan ons de Nāgarakṛtāgama wederom inlichten.

Zooals men weet, komt deze stichting ter sprake gedurende de groote reis van Rājasanagara door den Oosthoek, welke reis ongetwijfeld niet is te beschouwen als een maatregel van staatkundige contrôle, doch als een tirtha-, of, als wij dit woord mogen maken, een

1) Zie o.a. O.J.O. LXXXV: $3 \mathrm{a}: 1$.

2) Is deze veronderstelling juist, dan vervalt natuurlijk de in Oudheidkundige Aanteekening XXI (Bijdragen 89 (1932): 263 vlg.) in beschouwing genomen mogelijkheid, dat de poort Wringin Lawang op het gebied van het oude Majapahit iets met een bijzetting van Gajah Mada zou te maken gehad hebben. In het licht mijner latere opmerkingen inzake het voórkomen van tjandị's in of onmiddellijk bij de hoofdstad lijkt mij genoemde mogelijkheid ook om andere redenen geringer dan ik destijds vermoedde. 
dharmayātra. Waar bevond de vorst zich nu, toen ons vrijstift ter sprake kwam?

Hij had den volgenden weg afgelegd ${ }^{1}$ ). Vanuit Kapulungan had hij zich over Pañcuran en Kulur naar Batang (Gangan asěm) begeven, waar hij in het open veld kampeerde. Den volgenden dag ging het naar Bhayalangö, waar hij drie nachten bleef. Op den daarop volgenden dag ging men via Katang, Kĕḍung Dawa, Rame, Lampĕs, Timĕs, Kuți, Pogara, over de vlakte van Kagět, naar Daḍap in de mandala ${ }^{2}$ ) Hambulu traya. Daar gekomen wordt van Gajah Mada's dharma verteld, waarna wordt medegedeeld, dat alle kluizenaars en dorpelingen der buddhistische vrijstiften in de omgeving hunne hulde kwamen betuigen; zij kwamen van Gapuk, Gantěn, $\mathrm{Poh}^{3}$ ), Capahan $^{4}$ ), Kalampitan, Lumbang, Kuran, We Pĕtang, Pañcar, Tunggilis, Pabayĕman. Als vrijstiften, waartoe deze dorpen zouden behooren, worden genoemd die van İçānabajra en Ratnapangkaja.

1) Nāgarakṛtãgama zang 18 vlgg.

2) Er staat mwang ring maṇụala hambulu traya těke ḍaḍap adulur ikang rathālaris, hetgeen KeRN vertaalt: „en in 't distrikt Hambulu traya te Daḍap gekomen, zetten de wagens te gader den tocht voort". Dat maṇalala hier met "district" zou vertaald kunnen worden, lijkt mij zoo goed als uitgesloten. Immers, waar wij in dezen en den volgenden zang uitsluitend met buddhistische kluizenarijen en vrijgebieden te maken krijgen, spreekt het vanzelf, dat wij aan het woord mandiala dezelfde beteekenis moeten hechten, die het heeft in zang 78, waar Kern het vertaalt met (gewijde) kringen. Sinds de uitgave van de Tantu Panggělaran door PigEAud weten wij, wat wij onder zulk een mandala dienen te verstaan; het waren groepen van kluizenarijen, die op een of andere wijze samenhoorden. Dus dienen wij Kern's vertaling met "district" te vervangen door de bovengenoemde.

Dit brengt echter meerdere wijzigingen met zich mede.

Bedenkende, dat dergelijke mandala's bijna steeds in de bergen gelegen waren, wordt het onverstaanbaar, dat de dichter juist na aankomst in de mandiala Hambulu traya de wagens weder laat gebruiken. Zooals wij straks zullen zien, is dit Hambulu traya inderdaad in de bergen te localiseeren. Men zou dan ook veronderstellen, dat men in die mandala de wagens juist moest verlaten om te voet of met draagstoelen verder te gaan. Een meer met het zinsverband overeenkomende vertaling van těke kan deze moeilijkheid uit den weg ruimen; Kern vertaalt namelijk met „gekomen in”, doch indien wij vertalen met "totaan”, dan kunnen wij den geheelen laatsten regel van strophe 1 aldus weergeven:

„en in het gebied (der kluizenarij) Hambulu traya bleven de wagens medegaan totaan Dadap".

Wij moeten dus een plaats Daḍ̛ap veronderstellen, gelegen aan den rand van een bergstreek, welke Hambulu traya bevatte.

3) Ik kan mij met Krom's opmerking inzake den naam Poh in Nāg. pag. 266 niet goed vereenigen. Poh zonder nadere aanduiding komt wel degelijk voor. Zie T.B.G. LXVII (1927): 183 noot 27.

.4) Is dit hetzelfde als het capahan van zang $19: 2: 4$ ? 
Den volgenden dag gaat het dan verder oostwaarts.

Van al deze plaatsen zijn er nu enkele door Niermeyer terechtgebracht en wel met name de volgende.

Kapulungan $=$ Kapoeloengan bij Paṇdakan.

Kulur $=Z$. van Bangil.

Batang $=Z$. van Kapulungan.

Kĕḍung Dawa $=\mathrm{W}$. van Pasoeroehan.

Lampěs = Klampisan, W. van Pasoeroehan.

Hambulu traya $=$ Amboeloe bij Tongas (O. van Pasoeroehan).

Tunggilis $=$ misschien Tongas of Toegĕl (O. van Pasoeroehan).

Pabayĕman $=$ Bajĕman (O. van Pasoeroehan).

Hierbij zou ik echter willen opmerken, dat door de identificatie van Tunggilis met Tĕnggilis ( $Z$. van Pasoeroehan) door Callenfels, doch tevens door het feit, dat een Loembang, een Bajĕman en een Boeloe (uit Amboeloe?) alle Z. van Pasoeroehan liggen, en wel in de bergen en niet in de vlakte, deze plaatsen meer dan de door Niermeyer bedoelde in aanmerking komen voor een identificatie met die van het gedicht, aangezien het bronbezoek van den vorst ons in een bergstreek en niet in de vlakte verplaatst ${ }^{1}$ ). Hierdoor komt de streek, waar wij het Madakaripura kunnen verwachten, te liggen ongeveer recht ten Zuiden van Pasoeroehan en wel op de Noordhelling van den Tĕnggěr en dus niet in de buurt van Prabalingga op de N.O.-helling van dat gebergte ${ }^{2}$ ).

Met andere woorden, het gebied, dat volgens de Nāgarakrtāgama de dharma van Gajah Mada bevatte, was gelegen aan den toegang tot de streek, die wij beter kennen als die van het rijk van Singhasäri.

Maar dan is het ook zeker geen toevalligheid, als wij zien, dat nà

1) Stelt Poerbatjaraka (Bijdragen 80 (1924): 224) het tot de genoemde buddhistische stiften behoorende We pětang met recht gelijk aan modern Banjoe biroe, dan is er nog een reden te meer om Madakaripura ten Z. van Pasoeroehan te localiseeren. Hetzelfde geldt, als wij het tegenwoordige Patjar koening mogen vereenzelvigen met Pañcar. Het ligt Z.W. van Pasoeroehan.

2) Volgen wij een oogenblik de reis van den vorst, dan zien wij hem arriveeren bij een Ranu akuning, wat toch wel niet anders kan zijn geweest dan het tegenwoordige Ranoe klidoengan, het eenige meertje in de buurt (voor het bereiken der bergmeren bij Klakah is de in het gedicht verstreken tijdsduur veel te gering). Het volgende Kapayěman zou ik dan met het bij Prabalingga gelegen Bajĕman willen identificeeren, dat in de plaats van het bij Pasoeroehan gelegen Bajěman door Niermeyer werd aangezien voor het Pabayěman van zang 20 . Hierdoor wordt het verloop van de reis ook natuurlijker en met name de afgelegde afstand meer in overeenstemming met den daartoe benoodigden tijdsduur. 
den val van Majapahit een rijk, genaamd Gajah-Mada, gelocaliseerd wordt juist in die vlakte van Singhasāri, en dienen wij er rekening mede te houden, dat, uitgaande van het Madakaripura, dat in den volksmond zal geheeten hebben Gajah Mada-pura, en dat ongetwijfeld een erfelijke bezitting was, de nazaten van den grooten patih zich tot Heeren over bedoeld gebied kunnen hebben opgeworpen, daarbij steunende op oude rechten, hun door Rājasanagara geschonken. Een en ander lijkt mij te zeer voor de hand te liggen dan dat ons het bestaan van een rijk Gadjah-Mada na den val van Majapahit thans nog zou kunnen verbazen ${ }^{1}$ ).

\section{L.}

\section{Wat deed Ayam Wuruk te Kalayu?}

Zooals men weet, heeft Ayam Wuruk op zijn groote reis naar en door den Oosthoek in 1359 in de buurt van het tegenwoordige Kraksaän een heiligdom' bezocht, dat den naam Kalayu droeg en waar hij een ceremonie verrichtte, welke werd aangeduid met den term mamĕgat sigi ${ }^{2}$ ).

Het vers uit de Nāgarakṛtāgama, waaraan wij deze feiten ontleenen, luidt als volgt:

ikang kalayu dharmmasīma sugatapratișțāpagĕh/

mahottama sujanma wandhu haji sang dhinarmmeng dangū/

nimitta ni pakāryya kāryya haji dharmmakāryyādhika/

prasiddha maměgat sigi kawěkas i sudharmmenulah//31:2//

d.i. Dit Kalayu is een bijzettingsvrijgebied, een buddhistische geestelijke stichting. Een hoogaanzienlijke edelgeboren verwante van den

1) Ik wijs er hier nog op, dat het bovengenoemde Boeloe (voluit Boeloe kanduang geheeten) ligt bij de rivieren Boeloe goenting en Boeloe boerat. De namen van enkele andere rivieren in de onmiddellijke omgeving van dit Boeloe, namelijk Tjandi, Paridjata en Boejoetan, wijzen alle op een bijzettings-dharma in de buurt. Voorts ligt dit Boeloe (in tegenstelling tot het door Niermeyer aangewezen Amboeloe) in een onvervalscht brongebied, hetgeen wij op grond van Ayam Wuruk's bronbezoek moeten verwachten. Ayam Wuruk's wagens zouden dan, in de buurt van het huidige Winongan gekomen (detailbladen 1 : 50.000 no's LXXI A en XLII-55 B), den tocht hebben gestaakt, waarna de vorst zuidwaarts de bergen in getrokken zou zijn totaan het Madakaripura, dat hij wenschte te bezoeken. Wij zouden dus kunnen veronderstellen, dat genoemd heiligdom aan den voet van den Watoe godek (Těnggĕr) gelegen was.

2) Nāgarakṛtāgama, ed. KerN-KROM, p. 80. 
vorst is daar voorheen bijgezet. Daarom was de ceremonie, die de vorst daar verrichtte, de hoogste dharma-ceremonie: bekend is het mamĕgat sigi, dat op het einde van een godsdienstige stichting wordt verricht.

Kern teekent bij zijne vertaling (die slechts in kleinigheden van de bovengegevene afwijkt) ${ }^{1}$ ) nog aan: „Als ik het wel begrijp, heet maměgat sigi, letterlijk ,,afsnijden van 't ongeweven einde der schering van een weefsel", de handeling waarmee de vrome plechtigheden in 't heiligdom besloten werden. De symbolische strekking ervan is mij niet duidelijk." Terwijl Krom hier weder bij aanteekent, dat volgens Schrieke hetgeen de koning hier doet, zou beteekenen de conversie der wereldsche lasten van de omwonende bevolking in godsdienstige ${ }^{2}$ ).

Hier moet echter een vergissing in het spel zijn. Schrieke geeft op de door Krom opgegeven plaats zeer in het algemeen de redenen, welke den vorst in het oude Java tot het stichten van vrije desa's kunnen hebben gedreven, en noemt o.a. den eisch voor verzorging der graftempels. „Wat was eenvoudiger”, zoo gaat hij voort, ,dan de omwonende bevolking van verplichte opbrengsten of verplichten arbeid vrij te stellen en de conversie dezer wereldsche lasten in godsdienstige, die meestal zachter drukten, te verordenen.”, welke opvatting hij vervolgens in een noot met enkele plaatsen (w.o. de onze) staaft. Het komt mij voor, dat hij hierbij zeker niet aan de zeer speciale beteekenis van mamĕgat sigi zal hebben gedacht, doch zeer in het algemeen 's vorsten bemoeienis op het oog had; vandaar zijn andere verwijzing: „Krom-Brandes op. cit. (O.J.O.) passim” ${ }^{3}$ ).

Wij kunnen dan ook, in de overtuiging, dat Schrieke zich niet heeft willen uitlaten omtrent de speciale beteekenis van mamĕgat sigi, dezen locus ter zijde laten, en zien dan, dat Kern's opvatting tot nog toe onbestreden bleef.

Aan Kern en Krom is echter een andere plaats ontgaan, welke niettemin eenig licht op onzen term zou kunnen werpen.

In den catalogus-Groeneveldt heeft Brandes, ter verduidelijking van een elders voorkomende uitdrukking bhațāra kaki, het opschrift van een steen gepubliceerd, van onbekende herkomst, doch volgens be-

1) O.a. heb ik in mijn vertaling het dharma uit den vorm dharmasima meenen tot zijn recht te moeten laten komen; ook meen ik niet, dat wij het dharma uit regel 3 plotseling met „vroomheid” mogen vertalen.

2) Nāg. pag. 269.

3) T.B.G. LVIII (1918): 401, 402. 
doelden geleerde van Oost-Java afkomstig ${ }^{1}$ ). Dit opschrift luidt als volgt :

//o// dhana pakșa rūpa janma //o// sira sang makapūrbha tarukan māmgatakĕn sigi tunwanira iki $/ / \mathrm{o} / /=/ / \mathrm{o} / /$ pangrakșanira sang apañji harșa nngah i sīra hyang kaki //o//

Brandes geeft een andere woordscheiding van het laatste gedeelte (sangapañji harșanngah isīrahyang kaki), doch deelt mede, dat dit komt, omdat hij van den inhoud niet zeker was; van het laatste gedeelte geeft hij dan ook geen vertaling. Wel van het eerste, die luidt:

„(Çaka) 1125. Hij die een begin gemaakt heeft met de ontginning, heeft het nog ongeweven gedeelte van de schering (sigi) afgesneden (van den kain, dien hij, evenals een wever dat doet als hij meent, dat zijn weefsel geheel gereed is, beschouwde als afgewerkt). Dit is de plaats waar hij verbrand werd. Enz."

Brandes' opvatting van het māmgatakĕn sigi nog een oogenblik ter zijde latende, stel ik voor bedoeld opschrift als volgt te vertalen:

„(Çaka) 1125 (1203 A.D.). Dit zijn de verbrandingsresten van hem, die het vrijstift voor het eerst heeft gesticht met het doorsnijden van de schering. Sang Apañji Harșa is de bewaker er van, een jongere broeder van den heiligen (of zaligen) Kaki."

Om deze vertaling te verantwoorden merk ik in de eerste plaats op, dat volgens van der Tuuk de term tunwan zooveel kan beteekenen als ,,wat van een gebrande - lees : verbrande - overgebleven is ${ }^{2}$ )". $\mathrm{Nu}$ doet zich het feit voor, dat wij uit geen enkele bron iets weten omtrent de gewoonte de plek van verbranding (wat tunwan natuurlijk ook kan beteekenen) op bijzondere wijze in eere te houden, terwijl de bewijzen overvloedig zijn, dat de bijzetting der verbrandingsresten, in een tjandi of op andere wijze, aanleiding heeft gegeven tot een geheelen cultus en daarenboven teruggaat op een oude hinduistische gewoonte.

Voorts wil ik opmerken, dat tarukan gelijkgesteld kan worden met sima, dharma enz., hoewel het natuurlijk ook (en oorspronkelijk) de beteekenis van ontginning kan hebben ${ }^{3}$ ). In verband met het feit, dat echter bijna alle opschriften uit den oudjavaanschen tijd met de stichting van een dharma te maken hebben, geef ik aan deze beteekenis zonder aarzelen de voorkeur.

Voor nngah ten slotte verwijs ik naar van der Tuuk sub voce

1) Catalogus GroeneveldT pag. 327.

2) VAN DER TUUK, KBNW II: 566.

3) VAN DER TUUK, KBNW II : 594 en III: 191 (susuk IV). 


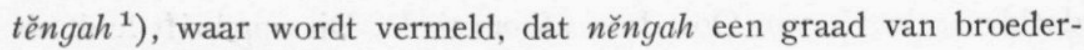
schap aanduidt, volgende op wayan. Wel is waar is er geen oogenblikkelijk bewijs te vinden, dat deze opvatting reeds in den ouden tijd bestond, doch zij ligt zoo voor de hand (middelste broeder), dat ik haar anvaard, tot het tegendeel bewezen kan worden; zij geeft in ieder geval zin.

Doch nu het mamĕgat sigi of māmgatakĕn sigi.

Het kwam mij reeds van den aanvang af voor, dat wij niet met Kern en Brandes moeten denken aan een symbolische handeling, doch aan een werkelijke, en, in verband met de waarde, die het weefsel bij de indonesische volkeren heeft, een magische. De symboliek toch, die bij geleerden van vroegere geslachten uit de studie der klassieken was overgenomen en toegepast op de verklaring van allerlei plechtige handelingen bij naar toenmalig inzicht primitieve volkeren, heeft haar tijd gehad en is in haar taak te kort geschoten. Willen wij dan ook dergelijke handelingen tot een goede verklaring brengen, dan dienen wij in de eerste plaats alle in onze wereld gebruikelijke methoden te verlaten en onze toevlucht te nemen tot de opvattingen dier volkeren zelve. En daarbij is reeds herhaaldelijk gebleken, dat de juiste kennis van de magische waarde, welke die volkeren aan zulke handelingen toekenden en waardoor zij deze als tastbare gevolgen hebbende ceremoniën beschouwden en niet als uitsluitend symbolische handelingen, ons op het rechte spoor hunner verklaring bracht. .

Aldus redeneerende, komt men er toe onder de bij diverse indonesische volkeren (en liefst die, welke op een of andere wijze met Majapahit in verband kunnen worden gebracht) bestaande gebruiken inzake het weven naar een parallel te zoeken. Dit zoeken wordt spoedig met succes bekroond, aangezien wij door de werkzaamheid van Damsté in staat gesteld zijn kennis te nemen van een door diverse bestuurders van Lombok verzameld aanzienlijk materiaal ${ }^{2}$ ).

Nemen wij dit materiaal door, dan blijkt al spoedig het volgende. Bij de belijders van den waktoe těloe genoemden godsdienst op Lombok, een slechts in geringe mate door den Islām aangetasten oudinheemschen godsdienst, spelen de zoogenaamde heilige weefsels ( $k \breve{e}$ kombong oemba') een zeer groote rol. Men kent daar standaarddoeken (kěkombong oemba') en copieën op kleinere schaal (moedjo mali').

1) VAN DER TUUK, KBNW II : 818 .

2) T.B.G. LXIII (1923) : 176 vlgg. Zie nog T.B.G. LXV (1925): 38 vlgg. 
De eerste worden door speciale pĕmangkoe's bewaard en worden slechts dan door nieuwe exemplaren vervangen, indien zij geheel versleten zijn, hetgeen natuurlijk met plechtigheden gepaard gaat. De copieën, de moedjo mali, komen echter bij diverse gelegenheden te pas, en wel voornamelijk bij ziekten, bij het haarsnijden van een jonggeborene, bij de besnijdenis en bij het huwelijk. De origineelen dienen voorts, behalve tot voorbeeld der copieën, tot het dragen van den pot, waarin heilig bronwater wordt gehaald ergens op een heilige plek-in de bergen of uit het Rindjani-meer.

Hoe gebruikt men nu de copieën ? Geven wij het woord aan den heer Pauw, die zulk een plechtigheid uitvoerig beschrijft ${ }^{\mathbf{1}}$ ).

„De betrokken familieleden gaan in optocht naar den pemangkoe, wiens oemba' zij de voorkeur geven, en halen het daar reeds gereed staande water. Zij leenen daar de oemba' (doorgaans hẹt mannelijke exemplaar) en dragen daarin het water in een kom onder gejuich en geschreeuw met gamelan naar de paposan ${ }^{2}$ ) - een vierkante, overdekte ruimte, ongeveer een meter boven den grond, waar de genoemde ceremoniën plaats vinden ${ }^{3}$ ) - Daar moeten het heilige water en de oemba' een nacht blijven, bewaakt door ouden van de dessa, die reciteerende den nacht doorbrengen (boedjangga's), terwijl offerschalen met spijzen rond de oemba' zijn opgesteld ${ }^{4}$ ).

Eerst den volgenden dag komen de kinderen, die de besnijdenis zullen ondergaan of wier hoofdhaar zal worden geschoren. Bij dergelijke ceremoniën wacht men doorgaans, totdat een aantal kinderen voor deze gebeurtenissen in de termen vallen om maar één paposan te behoeven te bouwen en kosten te sparen.

Intusschen hebben de ouders van de kinderen, die besneden zullen worden, een namaakweefsel vervaardigd van een der door den pemangkoe bewaarde standaard-modellen: de kekombongs oemba'. Dit namakweefsel is korter en smaller dan de oemba' en draagt geen

1) Ibidem pag. 187 vlg.

2) Dit luidruchtig optreden bij kleinere of groote ceremoniën is op Bali nog zeer gebruikelijk, hoewel daar schijnbaar geen reden voor te vinden is en dezelfde lieden even later hun gewone bedaardheid herkrijgen. Op Java is het nog slechts bij onceremoniëele gelegenheden op te merken. Naar het mij voorkomt, vindt het zijn grond in de behoefte aan levenskracht-versterking en is het dus een parallel van het zgn. lekoh (vuile praatjes), dat moet worden toegepast door hen, die, met het brengen van offers aan den Soenan Lawoe belast, een bepaalde hoogtegrens passeeren.

3) Te vergelijken dus met de kobongan der javaansche besnijdenis.

4) De offers wel op te vatten als magische versterkingen van de levenskracht van het heilige water of de oemba'. 
kepengs $\left.{ }^{1}\right)$. Na de geboorte van het betrokken kind is de moeder begonnen een der oemba's na te weven en thans is dit namaakweefsel (moedjo mali') gereedgekomen en wordt, aan de uiteinden nog niet doorgesneden ${ }^{2}$ ), meegebracht.

Zijn de kinderen in de peradja (draagstoel) in optocht rondgedragen, dan gaat men daarna in de paposan zitten en de moedjo mali' wordt doorgesneden door een der oudste gasten ${ }^{3}$ ).

Daarna wordt de franje aan de uiteinden in het heilige water gedoopt en boven de peradja drie malen rondgezwaaid om de hoofden der kinderen te besprenkelen, waarna vervolgens de besnijdenis of het hoofdhaarscheren plaats heeft. - De moedjo mali' blijft daarna bezit van den betrokken jongen en wordt door hem zorgvuldig bewaard of gebruikt als buikgordel (saboek)."

Ziehier dạn de wijze, waarop dergelijke doeken bij alle voorkomende plechtigheden worden gebruikt: zij worden - d.w.z. hunne schering wordt - doorgesneden, de uiteinden in heilig water gedoopt en met dit water wordt de betrokken persoon besprenkeld. Het is duidelijk, wat hier eigenlijk geschiedt: de ongesneden kain bevat onverminderd zijn gedurende het weven verkregen magische levenskracht. Door den kain open te snijden komt deze kracht er geheel of gedeeltelijk uit; gebruikt men nu die uiteinden om er heilig voorvader-water - bronnen staan met de voorvaderwereld in verband en het Rindjani-meer is zonder meer het meer uit den voorvaderhe$\mathrm{mel}^{4}$ ) - mede over iemand of iets te sprenkelen, dan werkt een en ander dubbel magisch ${ }^{5}$ ).

Hiermede is ook te verklaren het door de Roo de la Faille vermelde gebruik van dergelijke doeken op de bovenbeschreven wijze na afloop van het $n j e ̈ p i$, de zuiveringsperiode van de desa; immers bij het $n j e ̈ p i$ is men op het doode punt van de desa-levenskracht gekomen, de desa is dan gestorven; vandaar alle eigenaardige stilte-

1) De doorgesneden schering-franje van de oemba' wordt namelijk van kepeng's voorzien en samengeknoopt.

2) Cursiveeringen van mij.

3) $\mathrm{Bij}$ het balische haarsnijden worden de kinderen eveneens in een draagstoel rondgedragen en naar de huispoera gebracht, waar de plechtigheid plaats heeft. Voor zoover mij bekend, heeft daarbij echter geen doorsnijden van de schering plaats.

4) De danoem kakiringan der Dajaks; passim in den Archipel.

5) Dat bij haarscheren (levenskracht-centrum in het hoofd!) en bij besnijdenis (magische lichaamsopeningen) extra toevoer van levenskracht benoodigd is, behoeft geen betoog. Men kan de bewijsplaatsen overal in de ethnologische literatuur vinden. 
geboden enz. gedurende dien tijd. Door het gebruik der doeken wordt echter nieuwe levenskracht in de desa gebracht. Het gebruik bij ziekten laat zich eveneens op deze wijze verklaren.

Evenzoo is het al gesteld met de ceremonie, waarbij de standaarddoek te pas komt, als namelijk het heilige water uit de heilige bronnen verzameld wordt en in de oemba' naar de uit te planten padi wordt gebracht om deze daarmede te besprenkelen.

Opmerkelijk intusschen is het, dat in geen van de zeer uitvoerige berichten gesproken wordt van het doorsnijden dier doeken bij den dood; bij de begrafenisplechtigheden schijnt ook bij de waktoe těloelieden deze ceremonie ten eenenmale te ontbreken ${ }^{1}$ ). Hetgeen overigens niets verwonderlijks bevat, indien wij bedenken, dat het doorsnijden blijkbaar in de eerste plaats ten doel heeft het mededeelen van magische levenskracht en dus alleen ter sprake kan komen bij het beginnen van iets nieuws (een nieuw levensstadium bij haarsnijden, besnijdenis en huwelijk enz.).

Gewapend met deze kennis en eenig inzicht in doel en beteekenis van het doorsnijden van de schering, richten wij ons thans nog eenmaal tot de beide plaatsen in de oudjavaansche literatuur.

Thans wordt ons duidelijk, wat de bedoeling moet geweest zijn van het māmgatakĕn sigi van den stichter van een tarukan; het moet een ceremonie geweest zijn, welke de nieuwe stichting diende te voorzien van levenskracht en waarbij met de uiteinden van de doorgesneden schering heilig water (toya tīrtha) over het land werd gesprenkeld. Met andere woorden : ongeveer hetzelfde als het mamatingakěn hantlū $i$ sang hyang watu sima, het verpletteren van een ei tegen den oorkondesteen, een magische handeling, welke evenzeer de bedoeling moet hebben gehad aan den steen levenskracht te verschaffen ${ }^{2}$ ).

Maar hebben wij het hier bij het juiste einde, dan moet dezelfde

1) Ook voor Bali is mij onder de vele ceremoniën bij of na den dood niets omtrent het opensnijden van een gĕdogan (doek met onopengesneden schering) bekend. Wel wordt een gĕdogan van de bekende gĕringsing-doeken uit Těngahan gebezigd om er de wadah mede te versieren. Ook wordt een gĕdogan gebruikt bij de ceremonie van het tandenvijlen om zich er mede den mond af te vegen, en dienen zij als onderleggers voor ijzeren gereedschap enz. Van het doorsnijden en met de franjes besprenkelen kon ik echter voor Bali geen bewijsplaatsen vinden; kan hier de pědanda met zijn wijwaterkwast de taak van den pěmangkoe hebben overgenomen en dit gebruik daardoor in het vergeetboek zijn geraakt ?

2) De naam van een der lomboksche doeken (ragi pĕrigi Modjopait) kan op verband met dergelijke gebruiken op Java wijzen. 
term in de Nâgarakṛtāgama-plaats ook niet slaan op het beëindigen van de bijzettingsceremoniën, doch op het beëindigen van de ceremoniën der stichting van een dharma. Schijnbaar verzet zich daartegen het feit, dat een verwante van den koning daar eenmaal was bijgezet; schijnbaar, want zoowel dharmakärya als dharmenulah kan slaan op het stichten van een dharma, vrijstift. Blijkbaar heeft Ayam Wuruk dus van zijn tegenwoordigheid aldaar gebruik gemaakt om als hooge gast - men vergelijke hetgeen boven werd opgemerkt inzake het doorsnijden van de $o e m b a^{\prime}$ door een der oudste gasten $=$ hoogste in rang - de nog niet volbrachte ceremonie van het mamĕgat sigi, die het ,leven” moest schenken aan de stichting, te volbrengen. En dat zulks door den koning in eigen persoon geschiedde, zal de handeling magisch-krachtiger gemaakt hebben.

Of men uit deze verklaring der bedoelde woorden iets mag afleiden ten opzichte van het al dan niet aanwezig zijn van tjaṇ̣i Djaboeng op het oogenblik der handeling, betwijfel ik. Het monument kan er gestaan hebben, sinds de verwante des konings te Kalayu werd bijgezet, dus ing dangū. Het kan er echter ook pas gebouwd zijn na afloop van 's konings magische ceremonie. 